\title{
Analisis Tingkat Kerawanan Banjir di Kabupaten Semarang Menggunakan Overlay dan Scoring Memanfaatkan SIG
}

\author{
Dawa Rysqyqa Ramadhan ${ }^{1}$, Hanna Prillysca Chernovita ${ }^{2}$ \\ ${ }^{1}$ Teknik Sistem Informasi, Fakultas Teknologi Informasi, Universitas Kristen Satya Wacana \\ ${ }^{2}$ Teknik Sistem Informasi, Fakultas Teknologi Informasi, Universitas Kristen Satya Wacana \\ e-mail: ${ }^{1}$ rysqyqa@gmail.com,${ }^{2}$ hanna.chernovita@uksw.edu
}

\begin{abstract}
Abstrak: Bencana banjir merupakan bencana yang sering terjadi di wilayah iklim tropis khususnya daerah yang letaknya dikelilingi oleh aliran air atau genangan air seperti danau. Banjir di Indonesia dipengaruhi oleh pergantian musim yang tidak menentu yang menyebabkan bencana banjir. Penelitian ini bertujuan untuk memetakan wilayah yang rawan terhadap banjir dan mengetahui sebarapa besar tingkat kerawananan banjir yang dapat terjadi di studi area penelitian pada wilayah Kabupaten Semarang. Penelitian ini menggunakan metode overlay dengan tumpang susun layer, berdasarkan hasil perhitungan total scoring dari nilai dan bobot dari tiap parameter. Pengumpulan data dilakukan dengan mengumpulkan data sekunder berupa data spasial dan non spasial dari lembaga resmi Negara Indonesia, yang dipakai untuk mendukung analisis yang dilakukan. Dari hasil analisis yang dilakukan pada studi area penelitian di wilayah Kabupaten Semarang, diketahui terdapat 159 desa pada daerah dengan tingkat kerawanan yang rendah, serta 109 desa pada daerah dengan tingkat kerawanan sedang, sisanya 20 desa berada pada tingkat kerawanan tinggi. Dari analisis yang dilakukan, dapat ditarik kesimpulan bahwa wilayah Kabupaten Semarang khususnya pada daerah studi area penelitian menghasilkan informasi dari empat kecamatan yang ada, memiliki tingkat kerentanan yang didominasi oleh tingkat tidak rawan dan cukup rawan.
\end{abstract}

Kata kunci: Bencana Banjir, Overlay, Scoring, Sistem Informasi Geografi.

Abstract: Disaster flood disasters that occur in climatic areas, especially areas associated with water flows or puddles such as lakes. Floods in Indonesia are inspired by the changing seasons that are disastrous floods. This study aims to map the areas that are prone to flooding and how much danger is the level of flood vulnerability that can occur in the study area of Semarang Regency. This study uses an overlay method with overlapping layers, based on the calculation of the total score of the values and weights of each parameter. Data collection was carried out by collecting secondary data in the form of spatial data and non-official Indonesian institutions, which were used to support the analysis carried out. From the results of the analysis carried out in the study area of research in Semarang Regency, it is known that there are 159 villages in areas with low levels of vulnerability, as well as 109 villages in areas with moderate levels of vulnerability, the remaining 20 villages are at high levels of vulnerability. From the analysis carried out, it can be concluded that the Semarang Regency area, especially in the study area the research area produces information from the four existing subdistricts, has a level of vulnerability which is dominated by a level of vulnerability which is not vulnerable and quite vulnerable.

Keywords: Flood Disaster, Overlay, Scoring, Geographic Information System. 


\section{PENDAHULUAN}

Indonesia merupakan negara kepulauan yang memiliki letak geografis yang berada diantara pertemuan dua lempeng benua yaitu Sirkum Pasifik dan Sirkum Asiatik yang membuat Indonesia sering dilanda bencana alam. Selain dari hal tersebut Indonesia sendiri berada pada zona Tropis yang berakibat memiliki curah hujan yang tinggi sehingga potensi bencana banjir sangat mungkin terjadi. Menurut Suprapto (2011 : 35) Indonesia memiliki ancaman bencana banjir yang sangat besar jika dilihat berdasarkan ketinggian dataran rendah, cekungan serta daerah wilayahnya adalah lautan. Curah hujan pada daerah hulu berpotensi menyebabkan banjir di daerah hilir. Terutama daerah-daerah yang memiliki tinggi permukaan tanah lebih rendah atau hanya beberapa meter di atas permukaan air laut (Mardikaningsih et al., 2017). Iklim di Pulau Jawa termasuk dalam region A yang memiliki satu puncak hujan dan satu kemarau (Aldrian \& Dwi Susanto, 2003)

Indonesia mengalami dua pergantian musim yaitu musim kemarau dan musim penghujan karena berada pada daerah tropis, pada musim penghujan banyak terjadi bencana banjir di berbagai daerah di Indonesia. Pada daerah yang dekat dengan perairan, banjir air akan mudah terjadi karena volume air yang terlalu banyak yang mengakibatkan sungai tidak mampu mengalirkan air sampai kearah hilir. Akan tetapi saat ini pergantian musim terjadi tidak selaras karena adanya perubahan iklim dunia, salah satu sebab yang mengakibatkan terjadinya pergeseran musim di daerah Indonesia adalah fenomena Indian Ocean Dipole (IOD). Fenomena IOD merupakan suatu keadaan yang terjadi disebabkan adanya perbedaan anomali suhu pada permukaan laut di Samudera Hindia bagian barat dengan bagian timur (Nofiana Dian Rahayu, Bandi Sasmito, 2018).
Tingkat kerawanan banjir di daerah Kabupaten Semarang untuk dapat diketahui maka diperlukan analisis kerawanan bencana banjir pada lokasi yang akan dilakukan penelitian. Pada daerah yang diteliti akan dibuat pemetaan wilayah yang rawan akan terjadi bencana banjir, sehingga dapat diketahui daerah mana saja yang akan berpotensi terdampak bencana banjir. Pada penelitian ini akan berfokus pada analisis kerawanan bencana banjir di daerah yang menjadi lokasi penelitian, di Kabupaten Semarang khususnya daerah sekitar perairan Rawa Pening.

Kabupaten Semarang merupakan kabupaten yang terletak di Provinsi Jawa Tengah pada posisi $110^{\circ} 14^{\prime} 54,74^{\prime \prime}$ 110³9'3" Bujur Timur dan 7 $7^{\circ} 37^{\prime} 57^{\prime \prime}$ $7^{\circ} 30^{\prime} 0^{\prime}$ Lintang Selatan dengan memiliki luas 2,92\% (95.020,6 Ha) dari luas Provinsi Jawa Tengah. Hal tersebut menjadikan Kabupaten Semarang memiliki wilayah yang luas untuk dikelola karena terdapat 19 Kecamatan, 27 Kelurahan dan 208 Desa. Dengan daerah yang dikelilingi oleh perbukitan dan pegunungan serta banyak aliran sungai membuat Kabupaten Semarang rawan terhadap bencana alam (Restu Wigati, Andi Maddeppungeng, 2017.).

Lokasi yang akan menjadi penelitian ini akan berfokus pada daerah sekitar perairan Rawa Pening untuk dilakukan pengawasan terhadap risiko kebencanaan karena ada beberapa kecamatan yang berada dekat dengan daerah perairan Rawa Pening (Ignatius Wahyu Indriyanto, Bambang Sudarsono, 2019). Dengan kata lain terdapat empat kecamatan yang dilalui oleh perairan Rawa Pening yaitu Kecamatan Bawen, Kecamatan Ambarawa, Kecamatan Tuntang, Kecamatan Banyubiru memiliki ancaman bencana banjir yang dapat terjadi kapanpun. Pengawasan tersebut sangat perlu dilakukan untuk mengetahui seberapa tinggi maupun rendahnya tingkat rawan bencana banjir yang ada di dalam 
empat kecamatan Kabupaten Semarang tersebut.

Penggunaan teknologi informasi saat ini sudah berkembang pesat, sehingga pekerjaan pengawasan bencana dapat dengan mudah dilakukan secara cepat dengan menggunakan Sistem Informasi Geografis. Sistem Informasi Geografis yaitu suatu sistem yang tersusun atas perangkat lunak dan perangkat keras, data serta user, lalu bagian untuk menyimpan data-data yang berelasi dengan peristiwa yang ada pada muka bumi. Data-data berupa detail fakta, keadaan dan informasi spasial atau non spasial disimpan ke dalam basis data dan digunakan untuk bermacammacam keperluan analisis, manipulasi, penyajian dan sebagainya (Hamidi, 2007.). Proses identifikasi tingkat kerawanan bencana banjir dapat dilakukan melalui pemetaan pada tiap wilayah di Kabupaten Semarang secara akurat dengan Sistem Informasi Geografis menggunakan metode Overlay atau tumpang susun dengan mengacu pada beberapa parameter antara lain: kemiringan lahan, ketinggian lahan, curah hujan, penggunaan lahan. Dengan Sistem Informasi Geografis akan lebih mudah dalam menyajikan informasi spasial terkait dengan tingkat kerawanan bencana banjir yang berada di Kabupaten Semarang.

Penelitian ini dilakukan untuk menjawab rumusan masalah yang telah teridentifikasi yaitu bagaimana pemetaan wilayah yang rawan bencana banjir di Kabupaten Semarang? bagaimana tingkat kerawanan bencana banjir di wilayah Kabupaten Semarang? Penelitian ini juga bertujuan untuk untuk mengetahui pemetaan wilayah yang rawan bencana banjir di Kabupaten Semarang, untuk mengetahui tingkat kerawanan bencana banjir di wilayah Kabupaten Semarang. Maka akan diperoleh manfaat dari penelitian ini antara lain memberi informasi mengenai wilayah yang berpotensi terdampak Banjir di Kabupaten Semarang, memberi informasi tingkat resiko bencana banjir di Kabupaten
Semarang maka dapat menjadi acuan untuk melakukan penelitian selanjutnya mengenai kebencanaan banjir di Kabupaten Semarang.

\section{METODE PENELITIAN}

Pada Penelitian ini, metode yang digunakan dalam Analisis Tingkat Kerawanan Banjir adalah metode kuantitatif yang dilakukan dengan sistematis, serta terstruktur. Pada penyelenggaraanya metode riset ini berfokus terhadap penggunaan angka dan tabel guna menampilkan hasil data atau informasi yang diperoleh dengan menggunakan metode Overlay dan Scoring.

Penggunaan data dengan mengumpulkan data sekunder spasial dari Geoportal milik BIG dan BMKG. Waktu yang dibutuhkan untuk penelitian ini adalah tujuh bulan, dimulai dari bulan April tahun 2020 hingga bulan Oktober tahun 2020 dengan mempelajari pustaka dan data.

\section{Studi Pustaka:}

1. Mempelajari data sekunder berupa laporan laporan mengenai bencana banjir yang telah terjadi.

2. Mempelajari data curah hujan bulanan pada daerah yang sedang dilakukan penelitian.

3. Mempelajari peta curah hujan, peta topografi, peta penggunaan lahan.

4. Mempelajari teori analisis tingkat kerawanan bencana banjir.

\section{Pengumpulan Data}

Data yang dikumpulkan untuk mendukung penelitian ini antara lain:

1. Peta Dasar Indonesia yaitu peta perwilayah Kabupaten Semarang, skala 1:25.000.

2. Data curah hujan periode bulan Januari-Desember 2019 pada 5 stasiun cuaca BMKG yaitu stasiun BMKG Banjarnegara, stasiun BMKG Ahmad Yani, stasiun BMKG Semarang, 
stasiun BMKG Sleman, stasiun Cuaca Sleman, stasiun BMKG Tuban.

3. Buku Kebijakan Pengelolaan Tutupan Vegetasi Kabupaten Semarang tahun 2018, versi 1.

4. Buku Indeks Rawan Bencana Indonesia tahun 2018 oleh BNPB.

5. Dokumen Kajian Risiko Bencana (KRB) Provinsi Jawa Tengah Tahun 2016-2020.

\section{Analisis Data}

Analisis data yang dilakukan pada penelitian ini antara lain:

1. Menghitung rata-rata curah hujan tahun 2019 dengan proses IDW (inverse distance weighting) dan mereklasifikasi dengan Reclassify.

2. Membuat topografi dari data GMTED2010 dengan proses Hillsahde dan mereklasifikasi dengan Reclassify.

3. Membuat kemiringan dari data GMTED2010 dengan proses Slope dan mereklasikasi dengan Reclassify.

4. Analisis tutupan lahan dari data Landsat 8 dengan proses Supervised dan mereklasifikasi dengan proses Maximum Likehood Classification.

5. Membuat Skoring pembobotan dari semua data Reclassify dan melakukan penggabungan dengan proses Overlay (Union).

6. Mereklasifikasi hasil Overlay dengan Reclassify.

\section{HASIL DAN PEMBAHASAN}

\subsection{Profil Geografis Kabupaten Semarang}

Kabupaten Semarang merupakan salah satu kabupaten yang ada di wilayah Administrasi Provinsi Jawa Tengah, wilayahnya sebagian besar merupakan daratan tinggi dengan ketinggian rata-rata 544 meter diatas permukaan air laut. Dilihat dari letak geografis, Kabupaten Semarang memiliki batas antara lain: utara berbatasan dengan Kota Semarang, timur berbatasan dengan Kabupaten Grobogan, Kabupaten Demak, dan Kabupaten
Boyolali, selatan berbatasan dengan Kabupaten Boyolali, barat berbatasan dengan Kabupaten Kendal, Kabupaten Temanggung dan Kabupaten Magelang. Serta memiliki daerah perairan Rawa Pening yang dikelilingi oleh empat kecamatan yaitu: Kecamatan Ambarawa, Kecamatan Tuntang, Kecamatan Bawen, Kecamatan Banyubiru.

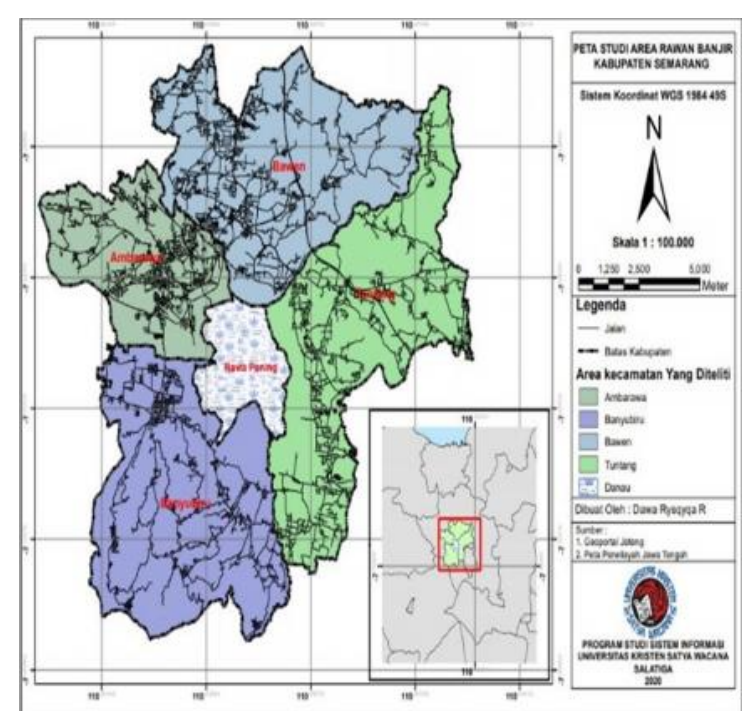

Gambar 1. Peta Studi Area Penelitian.

\subsection{Kerawanan Banjir}

Wignyosukarto (2009) menyatakan kerentanan merupakan suatu keadaan berkurangnya ketahanan yang dipengaruhi faktor eksternal antara lain Intensitas curah hujan, frekuensi dan lamanya hujan, karakteristik daerah aliran sungai yang dapat menjadi ancaman kehidupan. Berdasarkan faktor faktor di atas, dapat digunakan untuk parameter penelitian, yaitu:

\section{Kemiringan Lahan}

Kemiringan Lahan merupakan perbedaan diantara jarak vertical atau tinggi lahan terhadap jarak horizontal atau panjang lahan datar. Semakin panjang lahan datar terhadap jarak tinggi lahanya maka akan semakin besar potensi banjir yang dapat terjadi ataupun sebaliknya. Semakin besar tinggi jarak lahanya terhadap panjang lahan datar akan semakin aman atau semakin kecil potensi banjir yang dapat terjadi. Pada Tabel 1 disusun 
pemberian nilai parameter kemiringan lahan.

Tabel 1. Klasifikasi kemiringan lahan

\begin{tabular}{ccccc}
\hline No & $\begin{array}{c}\text { Kemiringan } \\
(\boldsymbol{\%})\end{array}$ & Deskripsi & Nilai & Bobot \\
\hline 1 & $0-8$ & Datar & 1 & \\
\cline { 1 - 4 } 2 & $9-15$ & Landai & 2 & \\
\cline { 1 - 3 } 3 & $16-25$ & $\begin{array}{c}\text { Agak } \\
\text { Curam }\end{array}$ & 3 & \multirow{2}{*}{30} \\
\cline { 1 - 3 } 4 & $26-45$ & Curam & 4 & \\
\cline { 1 - 3 } 5 & $>45$ & $\begin{array}{c}\text { Sangat } \\
\text { Cuam }\end{array}$ & 5 & \\
& & &
\end{tabular}

Sumber: (Listyani R.A., 2019)

\section{Ketinggian Lahan}

Ketinggian lahan merupakan suatu ketinggian tempat di atas permukaan air laut. Tinggi lahan mempunyai pengaruh pada terjadinya bencana banjir. Semakin rendah tingkat ketinggian tempat pada suatu daerah maka akan semakin besar potensi bencana banjir yang dapat terjadi ataupun sebaliknya. Semakin tinggi tingkat ketinggian lahan pada suatu daerah maka akan semakin aman atau semakin kecil potensi bencana banjir yang dapat terjadi. Pada Tabel 2 disusun pemberian nilai parameter ketinggian lahan.

Tabel 2. Klasifikasi Ketinggian Lahan

\begin{tabular}{cccc}
\hline No & Elevasi (m) & Nilai & Bobot \\
\hline 1 & $<10$ & 5 & \\
\cline { 1 - 3 } 2 & $10-50$ & 4 & \multirow{2}{*}{16} \\
\cline { 1 - 3 } 3 & $50-100$ & 3 & \\
\hline 4 & $100-200$ & 2 & \\
\hline 5 & $>200$ & 1 & \\
\hline
\end{tabular}

Sumber: (Nugraha, 2018)

\section{Curah Hujan}

Curah hujan merupakan banyaknya jumlah air hujan yang turun di suatu daerah dalam waktu tertentu. Curah hujan yang dibutuhkan untuk merancang pengendalian banjir adalah curah hujan rata-rata pada seluruh daerah yang berhubungan, bukan curah hujan di suatu titik yang tertentu biasa disebut curah hujan daerah. Semakin besar tingkat curah hujan maka semakin akan berpotensi terjadi bencana banjir ataupun sebaliknya. Semakin kecil tingkat curah hujan, maka semakin aman atau semakin kecil potensi bencana banjir yang dapat terjadi. Pada Tabel 3 disusun pemberian nilai parameter curah hujan.

\section{Tabel 3. Klasifikasi Curah Hujan}

\begin{tabular}{ccccc}
\hline No & $\begin{array}{c}\text { Curah } \\
\text { Hujan } \\
\text { Perbulan } \\
(\mathbf{m m})\end{array}$ & Deskripsi & Nilai & Bobot \\
\cline { 1 - 4 } 1 & $<1000$ & Kering & 1 & \\
\cline { 1 - 4 } 2 & $1000-2000$ & $\begin{array}{c}\text { Agak } \\
\text { Kering }\end{array}$ & 2 & \\
\cline { 1 - 3 } 3 & $2000-3000$ & Sedang & 3 \\
\cline { 1 - 3 } & $3000-4000$ & $\begin{array}{c}\text { Agak } \\
\text { Basah }\end{array}$ & 4 & \\
\hline 5 & $>4000$ & $\begin{array}{c}\text { Sangat } \\
\text { Basah }\end{array}$ & 5 & \\
\hline
\end{tabular}

Sumber: BMKG (2019) dan (Reza

Muhammadi \& Istika Nita, 2019)

\section{Penggunaan Lahan}

Penggunaan Lahan adalah hal yang mempengaruhi kerawanan banjir di suatu Kawasan/daerah. Penggunaan lahan berperan pada besarnya air limpasan dari hasil hujan yang sudah melebihi kemampuan infiltrasi. Lahan yang masih banyak ditanami oleh vegetasi maka air hujan mampu diinfiltasi serta perlu waktu lebih banyak pada limpasan untuk menempuh jarak sampai ke sungai sehingga potensi bencana banjir akan lebih rendah jika dibandingkan dengan daerah yang tidak tertanami oleh vegetasi. Pada Tabel 4 disusun penggunaan lahan yang ada.

Tabel 4. Klasifikasi Pengunaan Lahan

\begin{tabular}{|c|c|c|c|}
\hline No & Tutupan Lahan & Nilai & Bobot \\
\hline 1 & Hutan Tidak sejenis & 1 & \\
\hline 2 & Hutan Sejenis & 2 & \\
\hline 3 & Perkebunan & 3 & \\
\hline 4 & $\begin{array}{c}\text { Pemukiman, Sawah, } \\
\text { kolam }\end{array}$ & 4 & 27 \\
\hline 5 & $\begin{array}{l}\text { Tegalan, Tanah } \\
\text { Terbuka }\end{array}$ & 5 & \\
\hline
\end{tabular}

Sumber: (Sugianti \& Mulyadi, 2014) 
5. Analisis Tingkat Kerawanan Banjir

Formula yang digunakan dalam proses overlay dengan menggunakan metode aritmatika (Probo Kusumo, 2016) sebagai berikut:

$K B=((30 \times \mathrm{KL})+(16 \times \mathrm{E})+(27 \times \mathrm{CH})+$ $(27 \times \mathrm{PL}))$

Keterangan: KB (Kerawanan Banjir), KL (Kemiringan Lereng), $\mathrm{CH}$ (Curah Hujan), E (Elevasi), PL (Penggunaan Lahan).

\section{Klasifikasi Kelas Kerawanan Bencana} Banjir

Klasifikasi kelas kerawanan bencana banjir dapat diketahui dengan menggunakan perhitungan interval kelas dan ditunjukkan oleh persamaan pada no (1).

$$
=\frac{\text { Total Scoring }}{\text { nKelas }}(1)
$$

Tabel 5. Klasifikasi Kelas Kerawanan Bencana Banjir.

\begin{tabular}{cc}
\hline Interval Kelas & Kelas Kerawanan \\
\hline 1 & Tidak Rawan \\
\hline 2 & Cukup Rawan \\
\hline 3 & Sangat Rawan
\end{tabular}

Sumber: (Faizana et al., 2015)

\section{Scoring}

Penilaian scoring secara kualitatif bergantung dari pendapat para ahli. Berdasarkan pengalaman dari para ahli yang telah ditunjuk, bobot tertinggi ditunjukkan kepada parameter kemiringan lahan, dengan alasan rawan tidaknya suatu daerah akan ditentukan oleh kemiringan lahan daerah tersebut, karena akan mempengaruhi tingkat potensi banjir yang akan semakin tinggi. Selajutnya melihat parameter dari ketinggian lahan atau elevasi suatu tempat, ini dikarenakan semakin rendah suatu tempat akan semakin dekat dengan tempat tergenangnya air maka potensi dari daerah tersebut akan semakin besar untuk terjadi banjir. Selanjutnya adalah parameter curah hujan,

6 --- April bobot curah hujan memiliki nilai yang tidak terlalu tinggi dari parameter sebelumnya namun tetap berpengaruh terhadap faktor banjir, semakin besar tingkat curah hujan maka potensi bencana banjir yang kan terjadi juga semakin tinggi, akan tetapi pada tempat tertentu curah hujan tidak memliki pengaruh yang dominan khususnya di daerah yang tinggi dikarenakan untuk terjadi banjir akan bernilai bobot yang tidak terlalu besar. Parameter penggunaan lahan memiliki nilai yang sama dengan bobot pada parameter curah hujan karena tidak dominan dalam pengaruh terjadi banjir.

Scoring merupakan metode untuk mendapatkan nilai/skor total, maka diperlukan melakukan pemberian suatu penilaian serta pembobotan agar perkalian diantara pembobotan dengan penilaian akan menghasilkan nilai total yang disebut. Pada setiap parameter akan diberikan penilaian yang sama yaitu nilai 1 sampai 5 , tetapi pada pemberian pembobotan akan bergantung pada pengaruh dari setiap parameter yang mempunyai faktor yang paling besar dalam hal tingkat kerawanan banjir (Matondang et al., 2013). Pada Tabel 6 dapat dilihat Scoring.

Tabel 6. Parameter Scoring

\begin{tabular}{ccc}
\hline No & Parameter & Bobot \\
\hline $\mathbf{1}$ & Kemringan Lahan & 30 \\
\hline $\mathbf{2}$ & Ketinggian Lahan & 16 \\
\hline $\mathbf{3}$ & Curah Hujan & 27 \\
\hline $\mathbf{4}$ & Penggunaan Lahan & 27 \\
\hline & Jumlah & $\mathbf{1 0 0}$
\end{tabular}

Sumber: (Darmawan et al., 2017) dengan modifikasi penulis

\section{Overlay}

Overlay merupakan cara yang sangat penting dalam melakukan analisis pada Sistem Informasi Geografi. Overlay adalah kemampuan yang menempatkan visual satu peta di atas visual peta yang lain serta dengan menampilkan hasil yang ada pada plot. Sederhananya Overlay akan menumpang tindihkan layer satu ke layer 
yang lainya beserta dengan data atribut dari masing-masing layernya hingga akan menghasilkan layer gabungan yang memiliki informasi pada data atribut dari masing-masing layer gabungan oleh karena itu Overlay membutuhkan lebih dari satu layer ataupun peta (Tabel 7).

Tabel 7. Scoring.

\begin{tabular}{|c|c|c|c|c|}
\hline \multicolumn{5}{|c|}{ Parameter } \\
\hline No & $\begin{array}{l}\text { Kemiringan } \\
\text { Lahan }\end{array}$ & Nilai & Bobot & Skor \\
\hline 1 & $0-8$ & 1 & 30 & 30 \\
\hline 2 & $9-15$ & 2 & 30 & 60 \\
\hline 3 & $16-25$ & 3 & 30 & 90 \\
\hline 4 & $26-45$ & 4 & 30 & 120 \\
\hline 5 & $>45$ & 5 & 30 & 150 \\
\hline No & $\begin{array}{l}\text { Ketinggian } \\
\text { Lahan }\end{array}$ & Nilai & Bobot & Skor \\
\hline 1 & $<63$ & 4 & 16 & 64 \\
\hline 2 & $64-100$ & 3 & 16 & 48 \\
\hline 3 & $101-200$ & 2 & 16 & 32 \\
\hline 4 & $>200$ & 1 & 16 & 16 \\
\hline No & Curah Hujan & Nilai & Bobot & Skor \\
\hline 1 & $\begin{array}{c}246-253 \\
\mathrm{~mm} / \mathrm{bulan}\end{array}$ & 1 & 27 & 27 \\
\hline No & $\begin{array}{l}\text { Tutupan } \\
\text { Lahan }\end{array}$ & Nilai & Bobot & Skor \\
\hline 1 & $\begin{array}{c}\text { Hutan Tidak } \\
\text { sejenis }\end{array}$ & 1 & 27 & 27 \\
\hline 2 & Hutan Sejenis & 2 & 27 & 54 \\
\hline 3 & Perkebunan & 3 & 27 & 81 \\
\hline 4 & $\begin{array}{l}\text { Pemukiman, } \\
\text { Sawah, kolam }\end{array}$ & 4 & 27 & 108 \\
\hline 5 & $\begin{array}{c}\text { Tegalan, Tanah } \\
\text { Terbuka }\end{array}$ & 5 & 27 & 135 \\
\hline
\end{tabular}

Sumber: penulis

Pada parameter curah hujan didapatkan 1 klasifikasi dengan skor sebesar 27, lalu pada parameter ketinggian lahan mendapat 4 klasifikasi dengan skor tertinggi sebesar 64, serta parameter penggunaan lahan mendapatkan 5 klasifikasi dengan skor tertinggi sebesar 135.
Tabel 8. Nilai Kriteria Daerah Rawan.

\begin{tabular}{cll}
\hline No & \multicolumn{1}{c}{ Parameter } & Nilai \\
\hline 1 & Kemiringan lahan & 4,5 \\
\hline 2 & Curah Hujan & 4,5 \\
\hline 3 & Ketinggian Lahan & 3,4 \\
\hline 4 & Penggunaan Lahan & 4,5
\end{tabular}

Sumber: Penulis

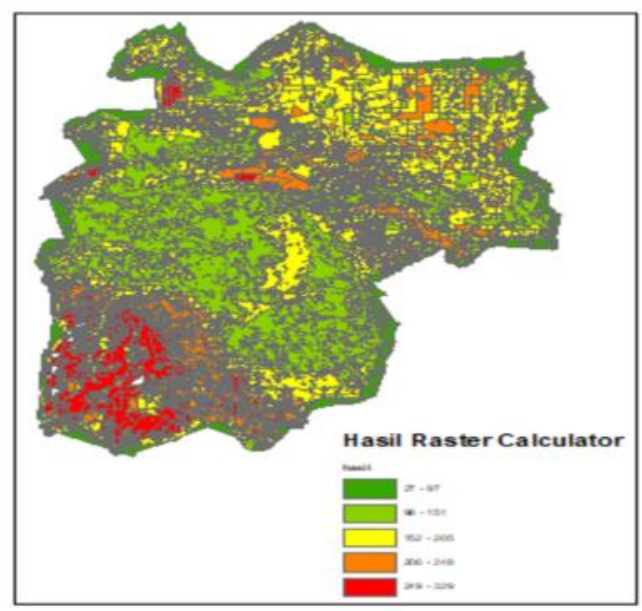

Gambar 2. Raster Calculator.

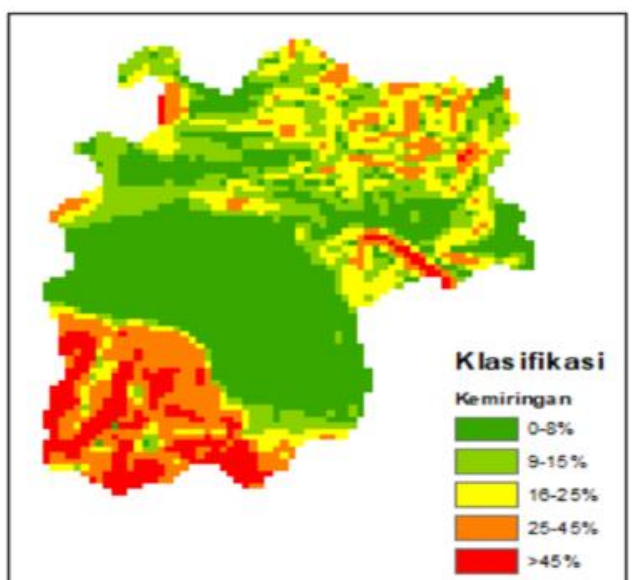

Gambar 3. Reklasifikasi Slope.

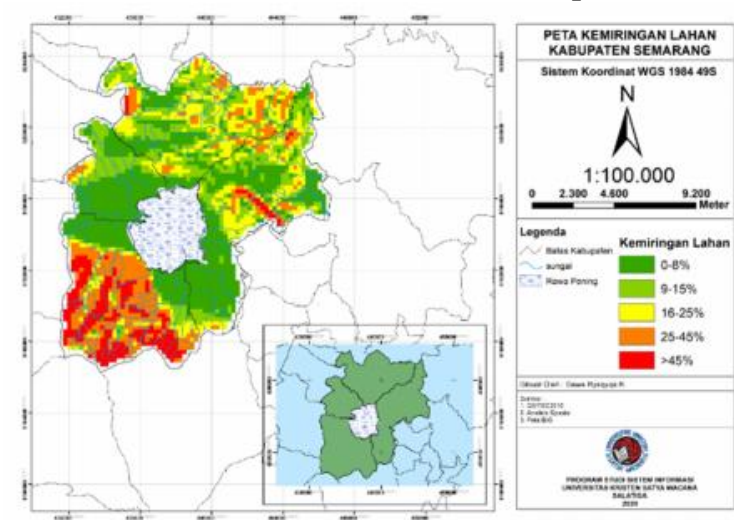

Gambar 4. Peta Kemiringan Lahan. April --- 7 
Wilayah studi area penelitian sebagian besar berada pada daerah yang memiliki tingkat kemiringan lahan dari 0 persen sampai kemiringan lebih dari 45 persen (Gambar 4).

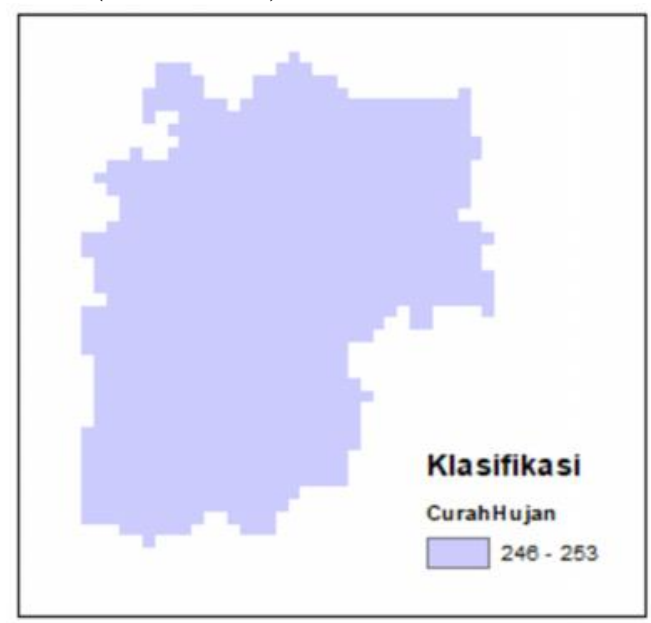

Gambar 5. Reklasifikasi Inverse Distance Weighting.

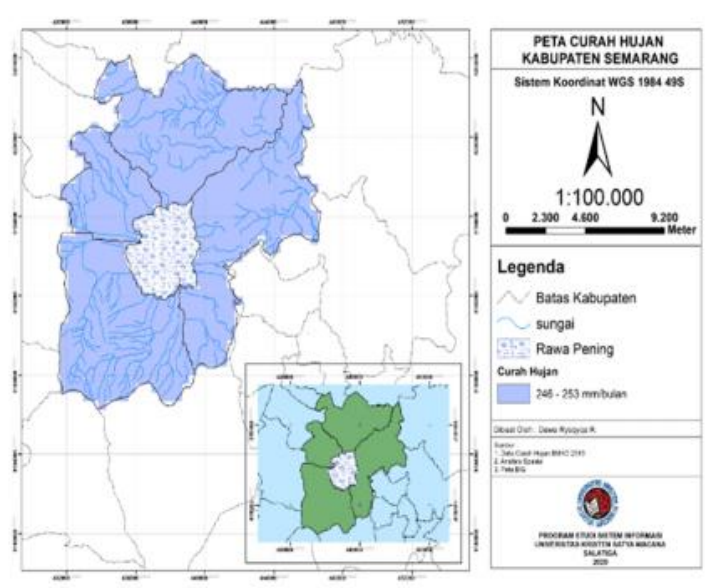

Gambar 6. Peta Curah Hujan.

Hasil pengolahan data non-spasial dari BMKG periode 2019 di 5 stasiun pengamatan BMKG di area Banjarnegara, Ahmad Yani, Semarang, Tuban, Sleman 1, Sleman 2 menunjukkan bahwa pada wilayah studi area penelitian tingkat curah hujan sebesar $253 \mathrm{~mm} /$ bulan bisa disebut kering (Gambar 5 dan Gambar 6).

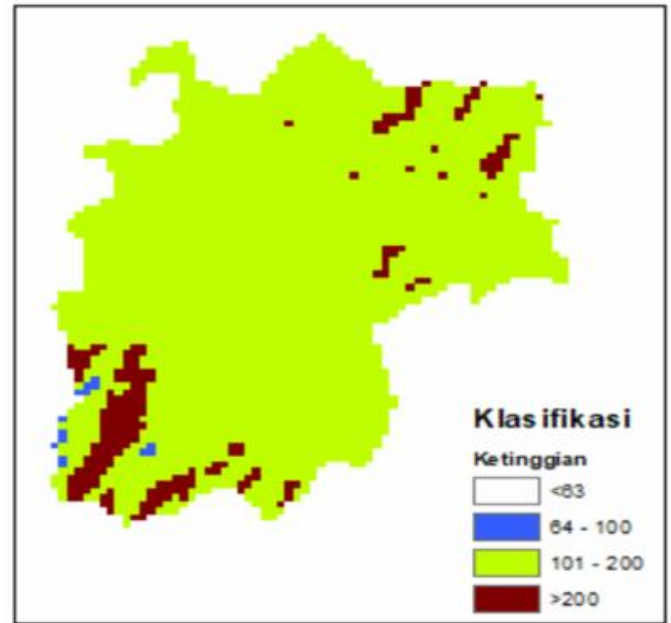

Gambar 7. Reklasifikasi Hillshade.

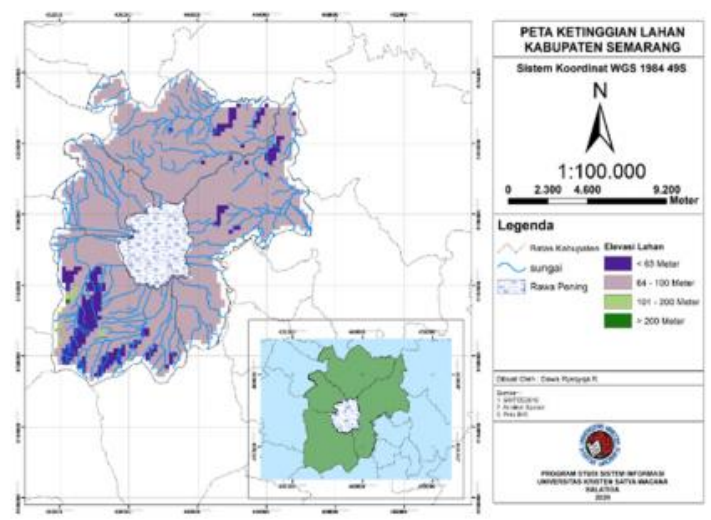

Gambar 8. Peta Ketinggian Lahan.

Di wilayah studi area penelitian menunjukkan titik terendah berada pada ketinggian 63 meter diatas permukaan laut dengan mayoritas ketinggian terletak pada 64 sampai 100 meter diatas permukaan laut (Gambar 7 dan Gambar 8).

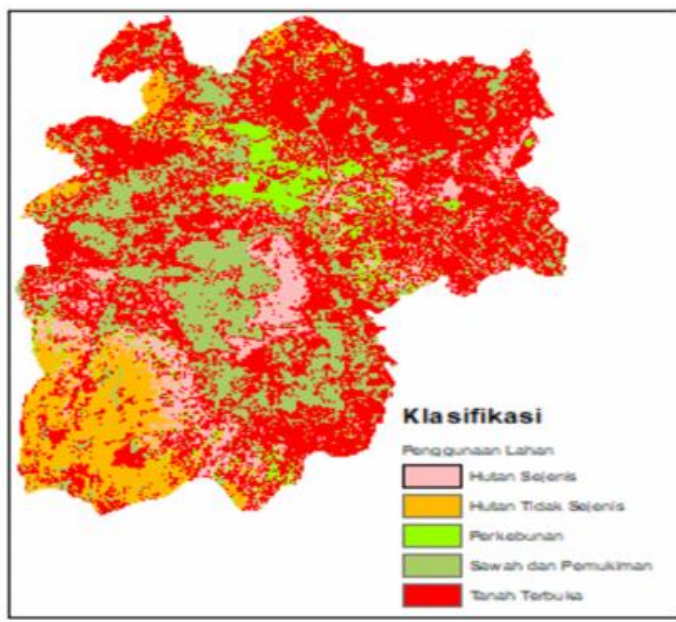

Gambar 9. Reklasifikasi Maximum Likehood Classification. 


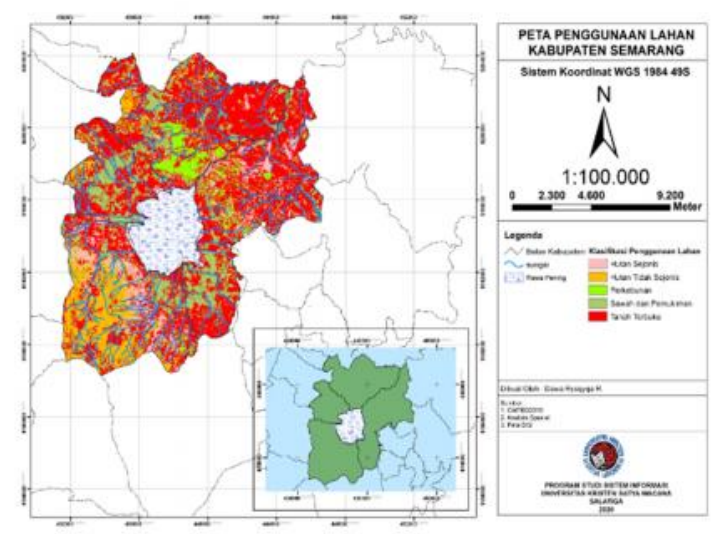

Gambar 10. Peta Penggunaan Lahan.

Berdasarkan pada penyelidikan penggunaan lahan pada wilayah studi area dengan mengolah foto citra landsat 8 dapat diketahui bahwa terdapat 5 jenis tutupan penggunaan lahan yang ada dengan mayoritas tegalan atau tanah terbuka (Gambar 9 dan Gambar 10).

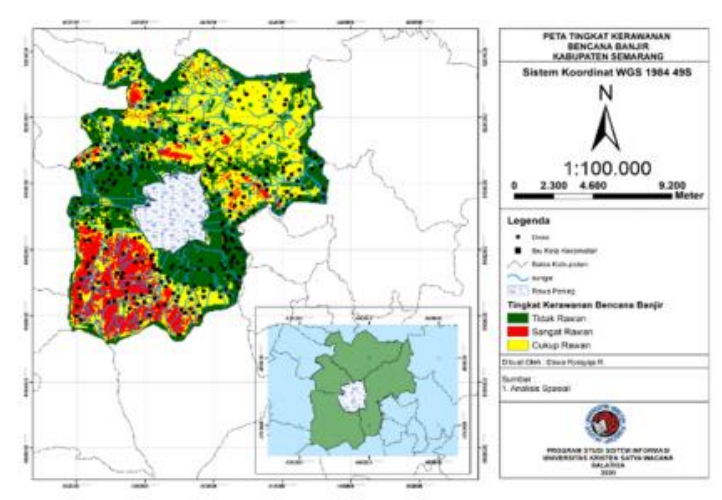

Gambar 11. Peta Tingkat Kerawanan Bencana Banjir.

\section{KESIMPULAN}

Proses analisis yang telah dilakukan, dapat ditarik kesimpulan bahwa pada wilayah Kabupaten Semarang khususnya pada daerah studi area penelitian menghasilkan informasi dari empat kecamatan yang ada, memiliki tingkat kerentanan yang didominasi oleh tingkat tidak rawan dan cukup rawan. Daerah yang tidak rawan atau aman berjumlah 159 desa, terletak di daerah yang memiliki curah hujan <2000 mm/bulan, ketinggian >64 meter, kemiringan $<25 \%$, penggunaan lahan di daerah hutan sejenis/berbeda. Sedangkan daearah cukup cukup rawan/sedang berjumlah 109 , terletak di daearah yang memiliki curah hujan 2000$3000 \mathrm{~mm} /$ bulan, ketinggian 64-100 meter, kemiringan 16\%-25\%, penggunaan lahan di perkebunan. Tidak seperti daerah yang tinggi kerawananya/bahaya berjumlah 20 desa, berada di daerah yang memiliki curah hujan $>3000 \mathrm{~mm} /$ bulan, kemiringan $>25 \%$, ketinggian $<63$ meter, penggunaan lahan di perkampungan dan tanah terbuka.

Diharapkan pada penelitian selanjutnya apat dilakukan penelitian yang membahas mengenai analisis pola hunian masyarakat yang bebas dari daerah bencana khususnya banjir.

\section{DAFTAR PUSTAKA}

E., Aldrian, R., Dwi Susanto. 2003. Identification of three dominant rainfall regions within Indonesia and their relationship to sea surface temperature. International Journal of Climatology. vol. 23, No. 12 , p. 1435-1452.

K., Darmawan, Hani'ah, A., Suprayogi. 2017. Analysis of Flood Hazard Levels in Sampang District Using Overlay Method with Scoring Based on Geographic Information Systems. Jurnal Geodesi Undip, vol. 6, No. 1, p. 31-40.

F., Faizana, A., Nugraha, B., Yuwono. 2015. Pemetaan Risiko Bencana Tanah Longsor Kota Semarang. Jurnal Geodesi Undip, vol. 4, No. 1, p. 223-234.

Hamidi.2007. Aplikasi Sistem Informasi Geografis Berbasis WEB Penyebaran Dana Bantuan Operasional. Jurnal Masyarakat Informatika, vol. 2, No. 3, p. 1-14.

I., Ignatius Wahyu, S., Bambang, B. S. 2019. Analisis Kesesuaian Perubahan Penggunaan Lahan Terhadap Rencana Tata Ruang Wilayah (RTRW) di Sekitar Danau Rawa Pening Kabupaten Semarang Tahun 2013 dan 2018. Jurnal Geodesi Undip, vol. 8, No. 4, p. 133-142. 
T., Listyani R.A. 2019. Criticise of Van Zuidam Classification: A Purpose of Landform Unit. Prosiding Nasional Rekayasa Teknologi Industri dan Informasi XIV Tahun 2019. Universitas ITNY: p. 332-337.

Mardikaningsih, S. M., Muryani, C., Nugraha, S. 2017. Studi Kerentanan dan Arahan Mitigasi Bencana Banjir di Kecamatan Puring Kabupaten Kebumen Tahun 2016. Jurnal GeoEco, vol. 3, No. 2, p. 157-163.

J., Matondang, S., Kahar, B., Sasmito. 2013. Analisis Zonasi Daerah Rentan Banjir Dengan Pemanfaatan Sistem Informasi Geografis (Studi Kasus: Kota Kendal Dan Sekitarnya). Jurnal Geodesi Undip. vol. 2, No. 2, p. 103113.

R., Nofiana Dian, S., Bandi, B., Nurhaidi. 2018. Analisis Pengaruh Fenomena India Ocean Dipole (IOD) Terhadap Curah Hujan di Pulau Jawa. Jurnal Geodesi Undip. vol. 7, No. 1, p. 5767.

Nugraha, A., L. 2018. Peningkatan Akurasi dan Presisi Analisa Spasial Pemodelan Banjir Kota Semarang Menggunakan Kombinasi Sistem Informasi Geografis Dan Metode Logika Fuzzy. Jurnal Teknik, vol. 39, No. 1, p. 16-24.
Kusumo, Probo, N., Evi. 2016. Zonasi Tingkat Kerawanan Banjir Dengan Sisitem Informasi Geografis Pada DAS Cidurian Kab. Serang, Banten. Jurnal String. vol. 1, No. 1, p. 29-38. Wigati, Restu, Maddeppungeng, Andi, P., Bella, D. 2017. Kajian Alternatif Penanggulangan Banjir ( Studi Kasus DAS Ciujung Bagian Hulu, Banten ). Jurnal Konstruksia. vol. 8, No. 2, p. 9-22.

M., Reza, R., Mochtar, L., N., Istika. 2019. Penerapan Sistem Informasi Geografi Dalam Pendugaan Sebaran Daerah Rawan Longsor di Kecamatan Ngargoyoso, Kabupaten Karanganyar. Jurnal Tanah dan Sumberdaya Lahan. vol. 6, No. 1, p. 1157-1163. 006.1.7

K., Sugianti, D., Mulyadi, D., Sarah. 2014. Pengklasan Tingkat Kerentanan Gerakan Tanah Daerah Sumedang Selatan Menggunakan Metode Storie. Riset Geologi dan Pertambangan. vol. 24, No. 2, p. 93-104. 